\title{
Biodegradation of agrowastes by lignocellulolytic activity of an oyster mushroom, Pleurotus sapidus
}

\author{
Muhammad Bilal* and Muhammad Asgher \\ Industrial Biotechnology Laboratory, Department of Biochemistry, University of Agriculture, Faisalabad, Pakistan.
}

Revised: 14 February 2016; Accepted: 28 April 2016

\begin{abstract}
Lignocellulosic biomasses derived from dedicated crops and agro-industrial waste materials are promising renewable resources for the production of fuels and other value added bio-products. The production of ligninolytic and cellulolytic enzymes from different lignocellulosic agricultural wastes by Pleurotus sapidus WC 529 was investigated in the current study. The production pattern of the enzymes was examined during the growth of the organism for a period of 10 days, and the enzyme activities were expressed in units $/ \mathrm{mL}$. Cultivation in the solid-state culture of banana stalk (BS) gave rise to higher levels of laccase, manganese peroxidase $(\mathrm{MnP})$ and lignin peroxidase (LiP) activities compared to the cellulolytic enzymes. Response surface methodology (RSM) was adopted to optimise the culturing conditions for maximum enzyme secretion. Optimal conditions yielding the highest enzyme activities were: initial $\mathrm{pH}, 4$; temperature, $35{ }^{\circ} \mathrm{C}$; moisture level, $60 \%$; inoculum size, $4 \mathrm{~mL}$, and incubation time, 120 hours. The crude lignocellulolytic enzyme extract presented potential efficiency for the delignification of different lignocellulosic substrates within 48 hours. The results suggested the feasibility of lignocellulolytic enzyme production using cost effective agro-industrial residues that can be effectively used for lignin biodegradation.
\end{abstract}

Keywords: Lignin degradation, lignocellulolytic activity, optimisation, Pleurotus sapidus, response surface methodology, solid-state fermentation.

\section{INTRODUCTION}

Lignocellulose is a macromolecular complex comprising lignin, cellulose and hemicellulose. Lignin is composed of heteropolymers resulting from the oxidative coupling of three $p$-hydroxycinnamyl alcohol monolignols: $p$-coumaryl, coniferyl and sinapyl alcohols. The recalcitrance of lignin against biodegradation is due to its bulky and aromatic nature that limits the accessibility of microbial enzymes and decreases its biodegradability. Therefore, the degradation of lignin is the key step to lignocellulose transformation (Silva et al., 2014).

White-rot basidiomycetous fungi are the principal organisms that possess remarkable potential to decompose and degrade wood lignocellulose (including recalcitrant lignin) efficiently. The extracellular enzymes, lignin peroxidase (LiP EC 1.11.1.14), manganese peroxidase (MnP EC 1.11.1.13), versatile peroxidase (VP EC 1.11.1.16) and laccase (EC 1.10.3.2) secreted by white-rot fungi (WRF) are considered to be crucial for biodegradation of lignin and lignocelluloses (Munir et al., 2015). LiP is able to oxidise various aromatic compounds, while $\mathrm{MnP}$ oxidises $\mathrm{Mn}^{+2}$ almost exclusively to $\mathrm{Mn}^{+3}$, which in turn degrades phenolic compounds. Laccases are blue copper-containing oxidases that reduce molecular oxygen to water and oxidise phenolic compounds. Similarly, the conversion of delignified cellulosic biomass to fermentable sugars requires the synergistic action of cellulolytic enzymes, including endo-1, 4- $\beta$-glucanase (EC 3.2.1.4; endo-cellulase), cellobiohydrolase (CBH, EC 3.2.1.91; exo-cellulase), and $\beta$-glucosidase (EC 3.2.1.21) (Ferreira et al., 2009; Goyal \& Soni, 2011; Mtui, 2012).

Compared with direct application of WRF, enzymatic treatment appears potentially better due to shorter treatment time, absence of lag phase, reduced sludge volume and ease of controlling the process. Further, the use of purified and/or immobilised ligninolytic enzymes raises the cost of industrial processes (Bilal \& Asgher, 2015). The crude fermented enzyme extract may also provide some accessory enzymes and mediators that 
mediate the catalytic cycle of WRF peroxidases and laccase that are otherwise removed during enzyme purification (Asgher et al., 2013a). There are several benefits of using WRF lignocellulolytic enzyme extracts for delignification of plant biomass:

i. The ligninolytic enzyme extracts from WRF also contain other accessory enzymes and mediators required for the action of these enzymes for complete degradation of lignin.

ii. The enzyme extracts may also contain cellulase enzymes that can simultaneously hydrolyse the exposed cellulose fibers of de-lignified biomass.

The present study focused on the elevated production of lignocellulolytic enzymes by $P$. sapidus utilising different agricultural waste substrates. The enzymes were subsequently employed for the biodegradation of lignin.

\section{METHODOLOGY}

\section{Biomass and chemicals}

Lignocellulosic biomass such as, wheat straw (WS) and rice straw (RS) were collected from Students Research Farms, University of Agriculture, Faisalabad, Pakistan; corn stover (CS) and corncobs (CC) were collected from Rafhan Maize Products Co. Ltd., Faisalabad, Pakistan; and sugarcane bagasse (SCB) and banana stalk (BS) were procured from the local fruit market and Crescent Sugar Mills, Faisalabad, Pakistan, respectively. The raw materials were milled (less than $5 \mathrm{~mm}$ mesh), washed, air dried, and stored in air tight containers at room temperature. All the chemicals and reagents were procured from Sigma-Aldrich (USA) and Merck (Germany) through local distributors and suppliers.

\section{Organism and inoculum preparation}

A pre-screened pure culture of $P$. sapidus WC 529 strain was obtained from Dr Nasir Ahmad Khan, Fungal and Mushroom Laboratory, Department of Plant Pathology, University of Agriculture, Faisalabad, Pakistan. Fungal inoculum was prepared by growing the fungus using a rotary shaker (Sanyo Gallenkemp, UK) at $150 \mathrm{rpm}$ and $30^{\circ} \mathrm{C}$, in a $250 \mathrm{~mL}$ flask filled with $100 \mathrm{~mL}$ of Kirk's basal medium containing: $10.0 \mathrm{~g} / \mathrm{L}$ glucose; $0.2 \mathrm{~g} / \mathrm{L}$ ammonium tartrate; $0.21 \mathrm{~g} / \mathrm{L} \quad \mathrm{KH}_{2} \mathrm{PO}_{4} ; 0.05 \mathrm{~g} / \mathrm{L} \quad \mathrm{MgSO}_{4} .7 \mathrm{H}_{2} \mathrm{O}$; $0.01 \mathrm{~g} / \mathrm{L} \mathrm{CaCl}{ }_{2} ; 0.001 \mathrm{~g} / \mathrm{L}$ thiamine; $10 \mathrm{~mL}$ Tween 80 $(10 \%) ; 10 \mathrm{~mL} 100 \mathrm{mM}$ veratryl alcohol; and $10 \mathrm{~mL}$ trace element solution; initial pH 4.5 (Yasmeen et al., 2013). After 5 days of cultivation, mycelia were homogenised using a Waring laboratory blender.

\section{Solid-state fermentation for enzyme production}

Solid-state fermentation (SSF) of designated biomasses was performed in triplicate fermentation flasks $(250 \mathrm{~mL})$ containing $5 \mathrm{~g}$ of lignocellulosic substrate, moistened with $10 \mathrm{~mL}$ of the standard basal medium. Prior to sterilisation in autoclave (Sanyo Labo Autoclave, Japan), $\mathrm{pH}$ of the medium (WTW pH-meter; InoLab $\mathrm{pH}$ 730) was maintained at 4.5 . About $5 \mathrm{~mL}$ of $P$. sapidus spore suspension was used to inoculate the flasks containing lignocellulosic substrates (wheat straw, corncobs, corn stover, rice straw, banana stalk and sugarcane bagasse). The inoculated flasks were placed in still culture incubator at $30^{\circ} \mathrm{C}$ for 10 days. After every alternate day, a sterile sample $(1 \mathrm{~mL})$ from each flask was taken and analysed for enzyme activities (Yasmeen et al., 2013).

\section{Enzyme activity assays}

\section{Ligninolytic enzymes}

LiP enzyme was assayed spectrophotometrically using the method reported by Tien and Kirk (1988) using veratryl alcohol as the substrate at $310 \mathrm{~nm}\left(\dot{\varepsilon}_{310}=9300\right)$. The activity of $\mathrm{MnP}$ was monitored by following the methodology of Wariishi et al. (1992) by using $\mathrm{H}_{2} \mathrm{O}_{2}$ as the reaction initiator at $270 \mathrm{~nm}$. Laccase activity was assessed by determining the oxidation of 2, 2 azinobis 3-ethylbenzthiazoline 6 sulphonate (ABTS) at $436 \mathrm{~nm}$ (Wolfenden \& Willson, 1982).

\section{Cellulolytic enzymes}

Endo-1,4-ß-glucanases was assayed using carboxymethyl cellulose (CMC) as the substrate and 3, 5-dinitrosalisylic acid (DNS) as the coupling reagent by the method of Gadgil et al. (1995). Exo-1,4-ß-glucanase activity was determined using $1.0 \%$ salicin as the reaction substrate with DNS as the coupling reagent (Gielkens, 1999). B-glucosidase was assayed according to Gadgil et al. (1995) using $1.0 \%$ avicel as the assay substrate.

\section{Optimisation of culture conditions}

Response surface methodology (RSM) with central composite design (CCD) was employed to determine the effect of each parameter on enzyme activities. The independent parameters like $\mathrm{pH}$, temperature, inoculum size, incubation time and moisture were used in the range of $2.0-6.0,20-40^{\circ} \mathrm{C}, 1.0-5.0 \mathrm{~mL}, 24-120$ hours and $40-60 \%$, respectively. A total number of 15 runs were carried out to estimate the coefficients for the production of lignocellulolytic enzymes. The data were subjected to analysis of variance (ANOVA) and 3D response 
surface graphs were constructed using DOE 8.0.7.1 trial version software to study the responses and interactions between the variables. The quality of the fit of this model was expressed by the coefficient of determination $\left(\mathrm{R}^{2}\right)$ in the same programme. The quadratic model equation for predicting the response function, i.e. optimum ligninolytic and cellulolytic activities $(\mathrm{U} / \mathrm{mL})$ was expressed using second order polynomial according to equation 1 (Yasmeen et al., 2013).

$Y(x)=b_{0}+\sum_{i=1}^{k} b_{i} x_{i}+\sum_{j=2}^{k} \sum_{i=1}^{j-1} b_{i j} x_{i} x_{j}+\sum_{i=1}^{k} b_{i j} x^{2}+e$

where $i$ and $j$ are linear and quadratic coefficients, respectively, while $b$ represents regression coefficient, $\mathrm{Y}$ is the ligninolytic or cellulolytic yield, $k$ is the number of factors optimised in the experiment and $e$ is the random error.

\section{Delignification of substrates and lignin determination}

Different volumes $(5,7.5,10,12.5,15.5 \mathrm{~mL})$ of the ligninolytic extract in combination with Na-malonate buffer $(50 \mathrm{mM}, \mathrm{pH} 4.5)$ was applied at $35^{\circ} \mathrm{C}$ for different time periods to degrade lignin. The percentage of lignin before and after treatment was calculated from each substrate according to Asgher et al. (2013a; b). The sample was dissolved in $10 \mathrm{~mL}(25 \% \mathrm{w} / \mathrm{v})$ of acetyl bromide in glacial acetic acid (GAA $\geq 99 \%$ ) by heating at $70{ }^{\circ} \mathrm{C} \pm 2{ }^{\circ} \mathrm{C}$ for $30 \mathrm{~min}$. After $30 \mathrm{~min}$, the dissolved sample was transferred to a volumetric flask $(200 \mathrm{~mL})$ containing a mixture of acetic acid and caustic soda in 1:1 ratio. The sample was diluted to $15 \mathrm{~mL}$ with $99 \%$ acetic acid, and the absorbance was read at $280 \mathrm{~nm}$.

\section{Statistical analysis}

The experiments were performed in triplicate and the data obtained was subjected to ANOVA to study the interaction between variables and the responses (enzyme activities). Tukey's honestly significant difference test was used to compare the means when statistical differences were observed at $\mathrm{p}<0.05$. CoStat computer package (version 6.303, PMB 320, Monterey, CA, 93940 USA) was used for statistical analyses.

\section{RESULTS AND DISCUSSION}

Different lignocellulosic substrates; wheat straw, corn cobs, corn stover, rice straw, banana stalk and sugarcane bagasse, were evaluated for ligninolytic and cellulolytic enzyme activities of the oyster mushroom $P$. sapidus. Among the substrates investigated the highest ligninolytic enzyme activities (LiP, MnP and laccase) were detected in banana stalk on the $4^{\text {th }}$ day after inoculation through solidstate fermentation (SSF). The crude extract contained 228.2, 153.4 and $59.2 \mathrm{U} / \mathrm{mL}$ of laccase, $\mathrm{MnP}$ and $\mathrm{LiP}$, respectively (Table 1). The detected enzyme activities were in agreement with earlier reports (Kalmis et al., 2008; Singh et al., 2012) highlighting that $P$. ostreatus, $P$. eryngii and $P$. sajor caju exhibit considerable laccase and $\mathrm{MnP}$ activities with only traces of LiP. The literature survey revealed that a large number of microorganisms, including bacteria, fungi and yeast produce lignin degrading enzymes (LDEs) but WRF, particularly Pleurotus species and Phanerochaete chrysosporium generally exhibit the most desirable quantities (Munir et al., 2015). However, the selection of a particular strain remains a tedious task, especially when commercially competent enzyme yields are needed to be attained; and it depends upon a number of factors, in particular upon the composition and nature of the lignocellulosic substrate and environmental conditions. The selection of a suitable substrate for enzyme production in a SSF process depends upon the cost and availability of the substrate, and thus may involve screening of several agro-industrial residues (Yasmeen et al., 2013).

In the case of cellulases, the maximum enzyme activities were recorded in fermented culture of banana stalk i.e., endoglucanase; $(0.158 \mathrm{U} / \mathrm{mL})$, exoglucanase $(0.098 \mathrm{U} / \mathrm{mL})$ and $B$-glucosidase $(0.118$ $\mathrm{U} / \mathrm{mL}$ ) (Table 2). Tellez et al. (2008) and Singh et al. (2012) have encountered very low concentrations of cellulolytic enzymes from all strains of Pleurotus. Among those, P. florida has been reported as the best cellulolytic enzyme producer exhibiting $0.48,0.102$ and $0.980 \mathrm{U} / \mathrm{mL}$ of endoglucanase, exoglucanase and ß-glucosidase, respectively (Goyal \& Soni, 2011). In a previous study, banana fruit stalks have been confirmed to be excellent solid substrates for the production of cellulolytic enzymes by Neurospora sitophila at optimised growth conditions of $\mathrm{pH} 5.0$ and $35^{\circ} \mathrm{C}$ (Asad et al., 2006).

\section{Optimisation of lignocellulolytic enzymes}

Response surface methodology (RSM) is a powerful statistical approach, which is widely used to optimise different factors for enzyme production during fermentation processes (Kotzamanidis et al., 2013). In comparison to the laborious one-factor optimisation at a time strategy, RSM is regarded as a more time saving and cost effective method. The application of this methodology is expected to provide the optimal values of 
Table 1: Production of ligninolytic enzymes by P. sapidus cultivated on different lignocellulosic substrates in SSF*

\begin{tabular}{|c|c|c|c|c|c|c|}
\hline \multirow[t]{2}{*}{ Substrates } & \multirow[t]{2}{*}{ Enzymes } & \multicolumn{5}{|c|}{ Enzyme activity after incubation (days) $(\mathrm{U} / \mathrm{mL})$} \\
\hline & & 2 & 4 & 6 & 8 & 10 \\
\hline \multirow[t]{3}{*}{ WS } & Lac & $168 \pm 2.72^{\mathrm{a}}$ & $193 \pm 3.27^{\mathrm{b}}$ & $179.3 \pm 2.49^{\mathrm{c}}$ & $199.1 \pm 2.16^{\mathrm{d}}$ & $213.25 \pm 3.13^{\mathrm{e}}$ \\
\hline & $\mathrm{MnP}$ & $118 \pm 1.46^{\mathrm{a}}$ & $116 \pm 2.94{ }^{a}$ & $142.1 \pm 3.64^{b}$ & $136.7 \pm 1.33 \mathrm{bc}$ & $125.2 \pm 2.21^{\mathrm{c}}$ \\
\hline & LiP & $44.4 \pm 1.37^{\text {a }}$ & $56.8 \pm 1.71^{\mathrm{a}}$ & $58.11 \pm 1.73^{\mathrm{b}}$ & $45.1 \pm 0.27^{\mathrm{b}}$ & $39.15 \pm 2.42^{\mathrm{c}}$ \\
\hline \multirow[t]{3}{*}{$\mathrm{CC}$} & $\mathrm{Lac}$ & $186 \pm 3.92^{\mathrm{a}}$ & $165 \pm 2.22^{b}$ & $160.9 \pm 3.15^{b}$ & $147.1 \pm 2.51^{\mathrm{c}}$ & $132.1 \pm 1.55^{\mathrm{d}}$ \\
\hline & $\mathrm{MnP}$ & $105 \pm 2.11^{\text {a }}$ & $111 \pm 2.12^{b}$ & $125.2 \pm 2.53^{\mathrm{c}}$ & $105.1 \pm 1.41^{\mathrm{c}}$ & $95.2 \pm 1.58^{\mathrm{d}}$ \\
\hline & LiP & $50.1 \pm 1.43^{\mathrm{a}}$ & $52.1 \pm 0.41^{\mathrm{a}}$ & $41.12 \pm 1.08^{b}$ & $47.1 \pm 1.32^{b}$ & $52.25 \pm 0.37^{\mathrm{c}}$ \\
\hline \multirow[t]{3}{*}{ CS } & Lac & $100 \pm 1.94^{a}$ & $183 \pm 3.42^{b}$ & $173.1 \pm 3.03^{b}$ & $175.3 \pm 1.76^{\mathrm{c}}$ & $138.26 \pm 3.34^{\mathrm{d}}$ \\
\hline & $\mathrm{MnP}$ & $131 \pm 1.23$ a & $99.1 \pm 1.92^{b}$ & $118.4 \pm 3.14^{\mathrm{c}}$ & $99.2 \pm 1.12^{\mathrm{c}}$ & $72.1 \pm 1.12^{\mathrm{d}}$ \\
\hline & LiP & $45.1 \pm 1.11^{\mathrm{a}}$ & $46.2 \pm 1.37^{\mathrm{b}}$ & $48.1 \pm 1.82^{b}$ & $55.15 \pm 0.6^{b}$ & $46.12 \pm 0.70^{b}$ \\
\hline \multirow[t]{3}{*}{$\mathrm{RS}$} & Lac & $174 \pm 2.13^{\text {a }}$ & $190 \pm 3.13^{b}$ & $186.4 \pm 3.21^{\mathrm{c}}$ & $100.1 \pm 1.12^{\mathrm{d}}$ & $165.11 \pm 1.31^{\mathrm{e}}$ \\
\hline & $\mathrm{MnP}$ & $121 \pm 1.16^{\mathrm{a}}$ & $132 \pm 2.16^{\mathrm{b}}$ & $130.2 \pm 3.62^{\mathrm{c}}$ & $105.1 \pm 1.16^{\mathrm{c}}$ & $121.1 \pm 1.26^{\mathrm{d}}$ \\
\hline & $\mathrm{LiP}$ & $30.1 \pm 1.61^{\mathrm{a}}$ & $44.2 \pm 0.64^{\mathrm{b}}$ & $34.25 \pm 1.34^{\mathrm{c}}$ & $38.22 \pm 0.47^{\mathrm{d}}$ & $45.2 \pm 0.81^{\mathrm{e}}$ \\
\hline \multirow[t]{3}{*}{ BS } & Lac & $167 \pm 2.12^{a}$ & $228.2 \pm 2.21^{\mathrm{b}}$ & $200.2 \pm 3.42^{c}$ & $162.3 \pm 1.92^{\mathrm{cd}}$ & $165.1 \pm 2.13^{d}$ \\
\hline & $\mathrm{MnP}$ & $140 \pm 1.91^{\mathrm{a}}$ & $153.4 \pm 3.18^{b}$ & $120.1 \pm 3.30^{c}$ & $118.2 \pm 1.26^{\mathrm{c}}$ & $98.1 \pm 2.42^{\mathrm{d}}$ \\
\hline & $\mathrm{LiP}$ & $42.2 \pm 1.18^{a}$ & $59.2 \pm 1.52^{b}$ & $43.25 \pm 1.19^{b}$ & $41.22 \pm 0.54^{c}$ & $39.02 \pm 0.17^{\mathrm{d}}$ \\
\hline \multirow[t]{3}{*}{$\mathrm{SCB}$} & Lac & $110 \pm 1.27^{\mathrm{a}}$ & $172 \pm 2.12^{\mathrm{a}}$ & $172.4 \pm 3.63^{b}$ & $163.2 \pm 2.54^{b}$ & $155.05 \pm 2.13^{c}$ \\
\hline & $\mathrm{MnP}$ & $126 \pm 2.13^{\mathrm{a}}$ & $104 \pm 2.13^{b}$ & $105.2 \pm 1.24^{b}$ & $86.16 \pm 1.03^{c}$ & $65.2 \pm 2.11^{\mathrm{d}}$ \\
\hline & LiP & $38.2 \pm 0.19^{a}$ & $43.1 \pm 1.12^{\mathrm{ab}}$ & $37.15 \pm 0.32 \mathrm{bc}$ & $39.13 \pm 0.38^{c}$ & $41.12 \pm 1.81^{\mathrm{c}}$ \\
\hline
\end{tabular}

Data are means of three replicates. Means within rows having different superscripts are significantly different at $\mathrm{p}<0.05$ " $\mathrm{pH}$ - 4.5; Temperature $-30^{\circ} \mathrm{C}$

LiP - lignin peroxidase; MnP - manganese peroxidase; Lac - laccase; WS - wheat straw; CC - corncobs; CS - corn stover; RS - rice straw; BS - banana stalk; SCB - sugar cane bagasse

Table 2: Production of cellulolytic enzymes by P. sapidus cultivated on different lignocellulosic substrates

\begin{tabular}{|c|c|c|c|c|c|c|}
\hline \multirow[t]{2}{*}{ Substrates } & \multirow[t]{2}{*}{ Enzymes } & \multicolumn{5}{|c|}{ Enzyme activity after incubation (days) $(\mathrm{U} / \mathrm{mL})$} \\
\hline & & 2 & 4 & 6 & 8 & 10 \\
\hline \multirow[t]{3}{*}{ WS } & EG & $0.07 \pm 0.01^{\mathrm{a}}$ & $0.094 \pm 0.07^{\mathrm{b}}$ & $0.083 \pm 0.05^{\mathrm{bc}}$ & $0.071 \pm 0.06^{\mathrm{bc}}$ & $0.08 \pm 0.01^{\mathrm{c}}$ \\
\hline & $\mathrm{CBH}$ & $0.062 \pm 0.02^{\mathrm{a}}$ & $0.053 \pm 0.04^{\mathrm{a}}$ & $0.052 \pm 0.02^{b}$ & $0.048 \pm 0.03^{\mathrm{bc}}$ & $0.043 \pm 0.01^{\mathrm{c}}$ \\
\hline & BGL & $0.05 \pm 0.01^{\mathrm{a}}$ & $0.078 \pm 0.03^{a}$ & $0.055 \pm 0.03^{b}$ & $0.041 \pm 0.02^{b}$ & $0.033 \pm 0.03^{\mathrm{c}}$ \\
\hline \multirow[t]{3}{*}{$\mathrm{CC}$} & EG & $0.087 \pm 0.03^{\mathrm{a}}$ & $0.099 \pm 0.01 \mathrm{ab}$ & $0.084 \pm 0.03 \mathrm{ab}$ & $0.068 \pm 0.02^{\mathrm{ab}}$ & $0.074 \pm 0.01^{b}$ \\
\hline & $\mathrm{CBH}$ & $0.067 \pm 0.01$ & $0.069 \pm 0.04$ & $0.058 \pm 0.02$ & $0.043 \pm 0.02$ & $0.045 \pm 0.02$ \\
\hline & BGL & $0.053 \pm 0.02$ & $0.067 \pm 0.03$ & $0.046 \pm 0.01$ & $0.042 \pm 0.04$ & $0.056 \pm 0.03$ \\
\hline \multirow[t]{3}{*}{ CS } & EG & $0.086 \pm 0.02^{a}$ & $0.118 \pm 0.08 \mathrm{ab}$ & $0.082 \pm 0.04 \mathrm{ab}$ & $0.069 \pm 0.06^{\mathrm{ab}}$ & $0.082 \pm 0.05^{b}$ \\
\hline & $\mathrm{CBH}$ & $0.058 \pm 0.04$ & $0.075 \pm 0.02$ & $0.057 \pm 0.02$ & $0.044 \pm 0.05$ & $0.039 \pm 0.03$ \\
\hline & BGL & $0.054 \pm 0.02^{\mathrm{a}}$ & $0.086 \pm 0.04 \mathrm{ab}$ & $0.066 \pm 0.01 \mathrm{abc}$ & $0.05 \pm 0.01 \mathrm{bc}$ & $0.035 \pm 0.05^{\mathrm{c}}$ \\
\hline \multirow[t]{3}{*}{ RS } & EG & $0.073 \pm 0.03^{a}$ & $0.098 \pm 0.03 \mathrm{ab}$ & $0.081 \pm 0.03^{b}$ & $0.073 \pm 0.02^{\mathrm{b}}$ & $0.083 \pm 0.02^{b}$ \\
\hline & $\mathrm{CBH}$ & $0.054 \pm 0.02^{a}$ & $0.066 \pm 0.05^{b}$ & $0.061 \pm 0.02^{\mathrm{c}}$ & $0.057 \pm 0.01^{\mathrm{c}}$ & $0.049 \pm 0.02^{\mathrm{d}}$ \\
\hline & BGL & $0.036 \pm 0.03$ & $0.044 \pm 0.02$ & $0.054 \pm 0.01$ & $0.047 \pm 0.02$ & $0.035 \pm 0.03$ \\
\hline \multirow[t]{3}{*}{ BS } & EG & $0.122 \pm 0.02^{a}$ & $0.128 \pm 0.02^{b}$ & $0.158 \pm 0.09 \mathrm{bc}$ & $0.137 \pm 0.12^{\mathrm{bc}}$ & $0.139 \pm 0.03^{c}$ \\
\hline & $\mathrm{CBH}$ & $0.063 \pm 0.06^{\mathrm{a}}$ & $0.074 \pm 0.09^{\mathrm{ab}}$ & $0.098 \pm 0.01 \mathrm{ab}$ & $0.071 \pm 0.06^{\mathrm{ab}}$ & $0.067 \pm 0.04^{b}$ \\
\hline & BGL & $0.068 \pm 0.05^{a}$ & $0.086 \pm 0.01^{\mathrm{ab}}$ & $0.118 \pm 0.08^{\mathrm{ab}}$ & $0.101 \pm 0.04^{\mathrm{b}}$ & $0.099 \pm 0.01^{b}$ \\
\hline \multirow[t]{3}{*}{$\mathrm{SCB}$} & EG & $0.092 \pm 0.07^{\mathrm{a}}$ & $0.075 \pm 0.03^{b}$ & $0.079 \pm 0.02^{\mathrm{c}}$ & $0.07 \pm 0.03^{\mathrm{d}}$ & $0.081 \pm 0.03^{\mathrm{d}}$ \\
\hline & $\mathrm{CBH}$ & $0.072 \pm 0.03^{a}$ & $0.059 \pm 0.02^{\mathrm{ab}}$ & $0.068 \pm 0.04^{\mathrm{c}}$ & $0.043 \pm 0.02^{\mathrm{d}}$ & $0.038 \pm 0.01^{\mathrm{e}}$ \\
\hline & BGL & $0.049 \pm 0.02$ & $0.047 \pm 0.02$ & $0.045 \pm 0.02$ & $0.039 \pm 0.02$ & $0.036 \pm 0.01$ \\
\hline
\end{tabular}

Data are means of three replicates. Means within rows having different superscripts are significantly different at $\mathrm{p}<0.05$

EG - endo 1, 4- $\beta$ glucanase, CBH - cellobiohydrolase, BGL - $\beta$ glucosidase

WS - wheat straw; CC - corncobs; CS - corn stover; RS - rice straw; BS - banana stalk; SCB - sugar cane bagasse 
the key parameters affecting the production of enzymes in a straightforward approach. Therefore, during the last few years, many researchers have attempted this technique to enhance the enzyme production by different microbial strains (Yasmeen et al., 2013). The ligninolytic enzyme activities have been widely investigated in $P$. sapidus than that of cellulolytic enzymes.

In the present study, optimum enzyme production was tested under the design of RSM with central composite design (CCD) using DOE 8.0.7.1 trial version software (Silva et al., 2014). Banana stalk that resulted in the highest production of lignocellulolytic enzymes was solely optimised through RSM. An experimental design of 15 runs with 5 factors and 5 levels i.e. $\mathrm{pH}(2$, $3,4,5$ and 6$)$, temperature $\left(20,25,30,35\right.$ and $\left.40{ }^{\circ} \mathrm{C}\right)$, inoculum size $(1,2,3,4$ and $5 \mathrm{~mL})$, incubation time (24, 48, 72, 96 and 120 hours) and moisture (40, 45, 50,55 and $60 \%$ ) was adopted. The results shown in Table 3 indicate that maximum ligninase activities were obtained under optimum conditions of $\mathrm{pH} 4.0$; temperature $30{ }^{\circ} \mathrm{C}$; inoculum size $4 \mathrm{~mL}$; moisture content $60 \%$, and incubation time 5 days. The activities of $\mathrm{LiP}(98.76 \mathrm{U} / \mathrm{mL}), \mathrm{MnP}(219.60 \mathrm{U} / \mathrm{mL})$ and laccase $(313.55 \mathrm{U} / \mathrm{mL})$ were substantially enhanced by optimising the culture conditions. Trial 7 presented greater crude cellulase activities, i.e., endoglucanase $(0.212 \mathrm{U} / \mathrm{mL})$, exoglucanase $(0.187 \mathrm{U} / \mathrm{mL})$ and ß-glucosidase $(0.217 \mathrm{U} / \mathrm{mL})$, resulted by the medium $\mathrm{pH} 4$, temperature $30{ }^{\circ} \mathrm{C}$, inoculum size $4 \mathrm{~mL}$ and moisture content $60 \%$, after 5 days of incubation (Table 3).

ANOVA (Table 4) for the response surface model was carried out to evaluate the predictability of the polynomial model at $95 \%$ confidence interval. The fit of developed models can be determined from the lack of fit values, which was significant and this condition indicated that the employed model fitted well to the lignocellulolytic enzyme production. In a previous study, 12 days incubation and $1.0 \%$ carboxyl-methyl cellulose (CMC) as carbon source supported greater production of cellulases. A temperature range of $35-40{ }^{\circ} \mathrm{C}$ and $\mathrm{pH}$ 5.0 was optimum for exo and endoglucanase production while $\beta$-glucosidase production was optimum at $30^{\circ} \mathrm{C}$ and pH 4.5 (Goyal \& Soni, 2011).

Figure 1 shows that the predicted value of the response (Y) from the model is in agreement with actual values over the selected range of independent variables, and a straight line confirms the normality of the data. The high degree of agreement between predicted and actual values indicated that the CCD can be employed successfully as an effective and reliable tool for optimisation of conditions for maximum production of lignocellulolytic enzymes. Response surface plots for laccase activities

Table 3: Optimisation of the fermentation parameters using central composite design (CCD) under RSM

\begin{tabular}{|c|c|c|c|c|c|c|c|c|c|c|c|}
\hline \multirow[b]{2}{*}{ Runs } & \multicolumn{5}{|c|}{ Variables } & \multicolumn{6}{|c|}{ Enzyme activities $(\mathrm{U} / \mathrm{mL})$} \\
\hline & $\mathrm{pH}$ & $\begin{array}{c}\text { Temp. } \\
\left({ }^{\circ} \mathrm{C}\right)\end{array}$ & $\begin{array}{l}\text { I.S. } \\
(\mathrm{mL})\end{array}$ & $\begin{array}{l}\text { I.T. } \\
\text { (hrs) }\end{array}$ & $\begin{array}{c}\text { Moisture } \\
(\%)\end{array}$ & $\mathrm{LiP}$ & $\mathrm{MnP}$ & Lac & EG & $\mathrm{CBH}$ & BGL \\
\hline 1 & 4 & 40 & 2 & 72 & 40 & 81.04 & 162.22 & 243.05 & 0.088 & 0.097 & 0.187 \\
\hline 2 & 3 & 30 & 5 & 48 & 50 & 62.5 & 106.3 & 163.61 & 0.103 & 0.069 & 0.062 \\
\hline 3 & 2 & 20 & 5 & 120 & 60 & 77.24 & 139.24 & 233.01 & 0.094 & 0.056 & 0.187 \\
\hline 4 & 2 & 40 & 3 & 24 & 50 & 78.42 & 192.48 & 156.66 & 0.109 & 0.165 & 0.075 \\
\hline 5 & 6 & 40 & 1 & 24 & 60 & 75.87 & 161.36 & 262.77 & 0.092 & 0.067 & 0.187 \\
\hline 6 & 6 & 20 & 1 & 72 & 50 & 79.56 & 124.65 & 162.38 & 0.093 & 0.066 & 0.087 \\
\hline 7 & 4 & 30 & 4 & 120 & 60 & 98.76 & 219.6 & 313.55 & 0.212 & 0.187 & 0.217 \\
\hline 8 & 4 & 20 & 3 & 48 & 55 & 85.87 & 101.31 & 151.66 & 0.104 & 0.168 & 0.109 \\
\hline 9 & 6 & 30 & 3 & 96 & 45 & 86.29 & 71.73 & 251.86 & 0.092 & 0.068 & 0.079 \\
\hline 10 & 2 & 35 & 1 & 24 & 40 & 67.24 & 95.93 & 181.38 & 0.088 & 0.064 & 0.085 \\
\hline 11 & 4 & 40 & 2 & 72 & 40 & 77.54 & 178.13 & 154.45 & 0.093 & 0.167 & 0.185 \\
\hline 12 & 2 & 40 & 4 & 96 & 55 & 55.24 & 106.56 & 240.56 & 0.092 & 0.068 & 0.086 \\
\hline 13 & 2 & 20 & 1 & 24 & 60 & 84.97 & 180.43 & 113.61 & 0.092 & 0.168 & 0.095 \\
\hline 14 & 6 & 40 & 5 & 120 & 60 & 59.65 & 146.76 & 237.56 & 0.173 & 0.175 & 0.111 \\
\hline 15 & 3 & 30 & 5 & 48 & 50 & 79.35 & 165.32 & 207.37 & 0.109 & 0.169 & 0.083 \\
\hline
\end{tabular}

An average absorbance of the three repetitions was used in the calculations. Temp - temperature; I.S. - inoculum size; I.T. - incubation time; LiP - lignin peroxidase; MnP - manganese peroxidase; Lac - laccase; EG - endo 1, 4- $\beta$ glucanase, CBH - cellobiohydrolase, BGL - $\beta$ glucosidase 
Table 4: Analysis of variance (ANOVA) for laccase production in solid-state fermentation

\begin{tabular}{|c|c|c|c|c|c|}
\hline Source & SS & Df & MS & F-value & p-value \\
\hline Model & 5.767 & 20 & 2.884 & 4.95 & 0.0064 significant \\
\hline A & 4.555 & 1 & 3.831 & 6.57 & 0.0282 \\
\hline B & 2.97 & 1 & 4.555 & 0.78 & 0.3974 \\
\hline $\mathrm{C}$ & 4.017 & 1 & 2.97 & 5.1 & 0.0476 \\
\hline $\mathrm{D}$ & 7.236 & 1 & 4.017 & 6.89 & 0.0254 \\
\hline E & 1.642 & 1 & 7.236 & 12.42 & 0.0055 \\
\hline $\mathrm{AB}$ & 5.413 & 1 & 1.642 & 2.82 & 0.1242 \\
\hline $\mathrm{AC}$ & 4.717 & 1 & 4.717 & 9.29 & 0.0123 \\
\hline $\mathrm{AD}$ & 7.982 & 1 & 7.982 & 8.09 & 0.0174 \\
\hline $\mathrm{AE}$ & 4.169 & 1 & 4.169 & 1.37 & 0.2691 \\
\hline $\mathrm{BC}$ & 4.727 & 1 & 4.727 & 7.15 & 0.0233 \\
\hline $\mathrm{BD}$ & 2.429 & 1 & 2.429 & 8.11 & 0.0173 \\
\hline $\mathrm{BE}$ & 3.421 & 1 & 3.421 & 4.17 & 0.0685 \\
\hline $\mathrm{CD}$ & 5.746 & 1 & 5.746 & 5.87 & 0.0359 \\
\hline $\mathrm{CE}$ & 5.57 & 1 & 5.57 & 9.86 & 0.0105 \\
\hline $\mathrm{DE}$ & 1.061 & 1 & 1.061 & 9.56 & 0.0114 \\
\hline $\mathrm{A} 2$ & 1.474 & 1 & 1.474 & 1.82 & 0.2071 \\
\hline B2 & 6.537 & 1 & 6.537 & 2.53 & 0.1429 \\
\hline $\mathrm{C} 2$ & 2.175 & 1 & 2.175 & 0.11 & 0.7446 \\
\hline D2 & 6.781 & 1 & 6.781 & 3.73 & 0.0822 \\
\hline E2 & 5.829 & 1 & 5.829 & 1.16 & 0.3061 \\
\hline Residual & 5.429 & 1 & 1.086 & & \\
\hline Lack of Fit & 4 & 1 & 8 & 13.57 & 0.0062 significant \\
\hline Pure Error & 6.35 & 1 & & & \\
\hline \multirow[t]{4}{*}{ Cor Total } & & 1 & & & \\
\hline & & 1 & & & \\
\hline & & 5 & & & \\
\hline & & 30 & & & \\
\hline
\end{tabular}

SS - sum of squares; Df - degree of freedom; MS - mean square

[Figure 2 (A-D)] indicated that low temperature within the range tested had a significant influence on the lignocellulolytic enzyme production. Maximum enzyme activities were recorded when the temperature tended to be $35{ }^{\circ} \mathrm{C}$. Nonetheless, P. sapidus strain was not able to grow when incubated at temperatures below $20{ }^{\circ} \mathrm{C}$. Fernandez-Fueyo et al. (2014) reported that extreme temperature $\left(10{ }^{\circ} \mathrm{C}\right.$ and $\left.37^{\circ} \mathrm{C}\right)$ ranges led to marked reduction in enzyme activities. Yasmeen et al. (2013) also described a maximum ligninolytic enzyme secretion by Ganoderma luciduma and Schyzophilum commune at $35{ }^{\circ} \mathrm{C}$ and $4.5 \mathrm{pH}$. When considering the $\mathrm{pH}$, optimum activities of LDEs were achieved at $\mathrm{pH}$ 4.0 with a moderate temperature level $\left(35^{\circ} \mathrm{C}\right)$. Beyond this optimal $\mathrm{pH}$, the activities of LDEs substantially declined. Fernandez-Fueyo et al. (2014) observed reduced $P$. ostreatus enzyme profiles at extreme $\mathrm{pH}$ values (3.0 and 8.0), whereas Wang et al. (2014) noted enhanced enzyme production by $T$. versicolor in an

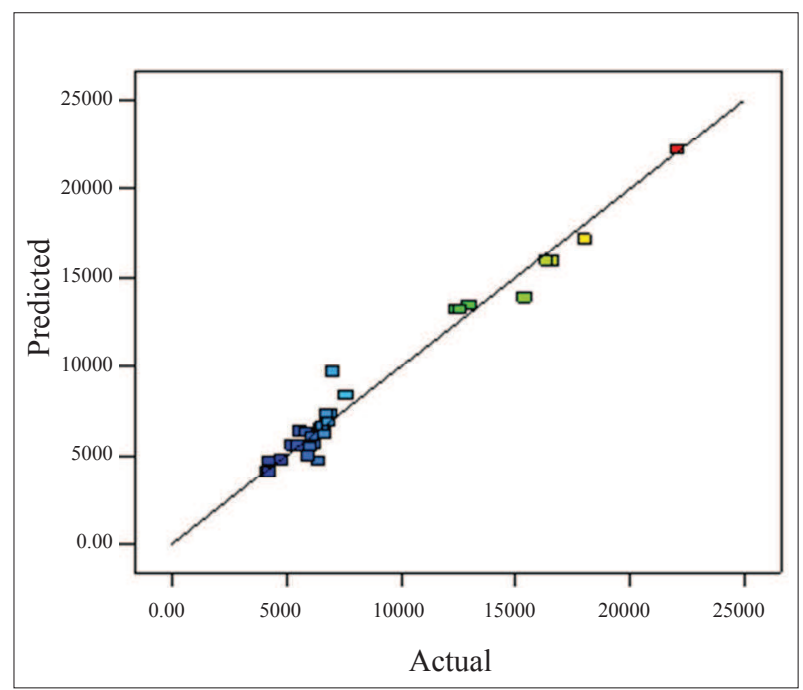

Figure 1: Predicted and actual values for laccase enzyme production 


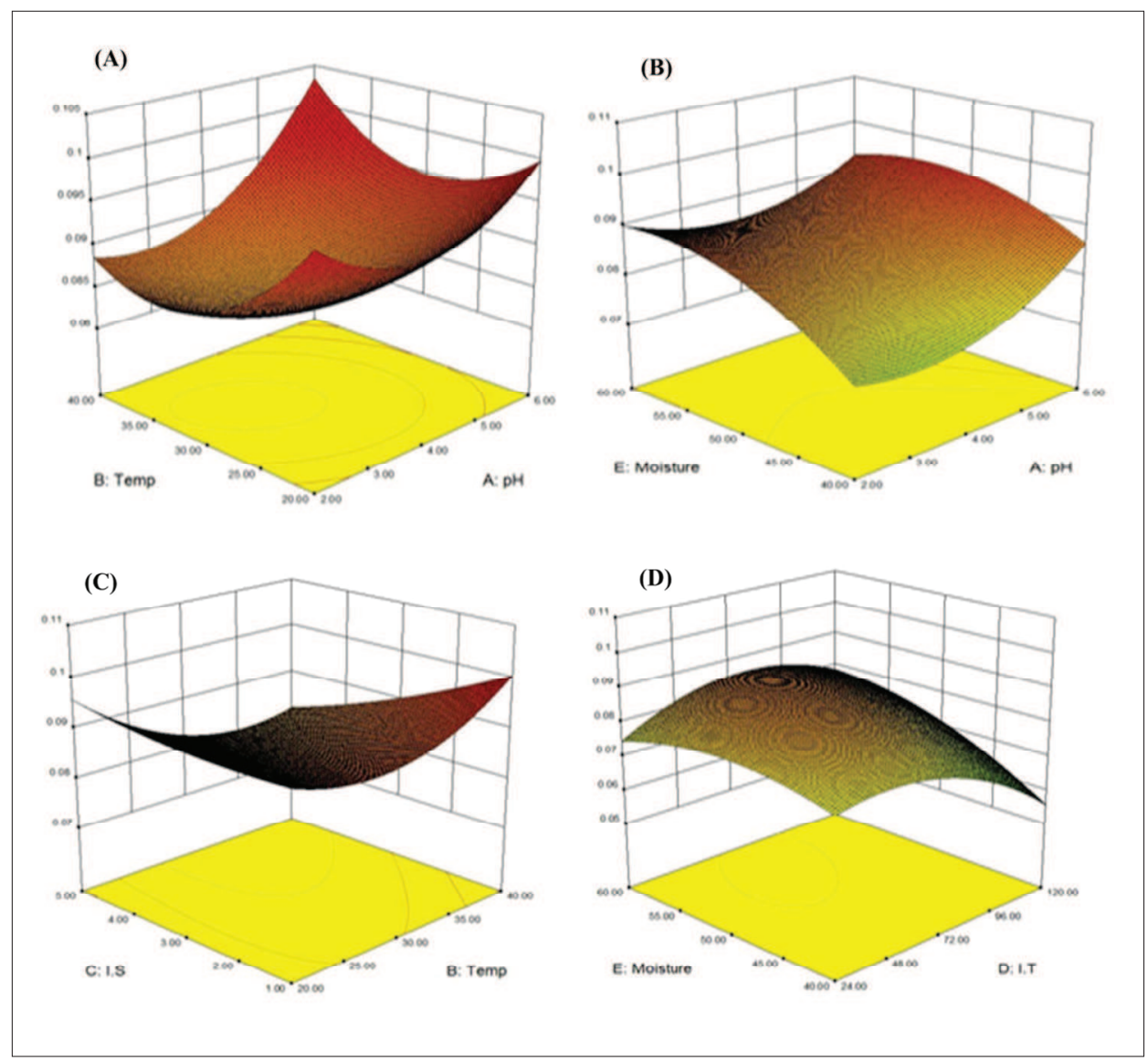

Figure 2: Response surface plots showing the interactive effect of (A) $\mathrm{pH} v s$ temperature; (B) $\mathrm{pH} v s$ moisture; (C) temperature $v s$ inoculum size, and (D) incubation time $v s$ moisture for optimisation of laccase enzyme

acidic $\mathrm{pH}$ of 4. Solid-state fermentation (SSF) of plant biomasses promoted the production of ligninolytic enzymes than submerged fermentation $(\mathrm{SmF})$ by several Pleurotus strains (Yasmeen et al., 2013). Vassilev et al. (2009) found the highest activities at $37^{\circ} \mathrm{C}$ temperature, $60 \%$ humidity and $\mathrm{pH} 5.0$ after a 21 day process by P. chrysosporium. Using Trametes villosa with optimised cultivation conditions, Silva et al. (2014) determined a 15 days best time for the production of MnP, after which it declined until approaching zero on the $30^{\text {th }}$ day.

\section{Lignin degradation}

The crude lignocellulolytic extract in varying dose levels $(5,7.5,10,12.5,15.5 \mathrm{~mL})$ was used for the delignification of selected agricultural wastes for different time periods, and the responses are illustrated in Figure 3. The lignin content in all the substrates was reduced after ligninolytic treatment and maximum delignification was recorded in rice straw, followed by sugarcane bagasse, corn cobs and wheat straw after 48 hours. Different percentages of lignin removal in different substrates may be attributed to differences in cell wall assembly, the complicated structure of lignin and lignin-carbohydrate complex. Nevertheless, the lignin degradation trend achieved in the present study was in agreement with previous studies. Taniguchi et al. (2005) achieved $41 \%$ klason lignin removal from pretreated rice straw by $P$. ostreatus. Asgher et al. (2013a) managed to achieve $33.5 \%$ reduction in the lignin content of sugarcane bagasse and Wang et al. (2014) degraded lignin up to $34.7 \%$ in rice straw. Silva et al. (2014) by applying crude enzyme extract from Trametes villosa (Sw.) Kreisel CCMB 651 caused $35.05 \%, 63.11 \%$ and $39.61 \%$ reduction in lignin content for sugarcane bagasse, sisal fiber and coconut shell, respectively. Although all cited reports showed good results, none of the studies reached the degree of lignin removal achieved in the present ligninolytic based treatment that caused commendable delignification of all studied agricultural wastes under mild and ecofriendly processing conditions, which are safer and more stable than various alkali, acidic or other pre-treatment techniques. 


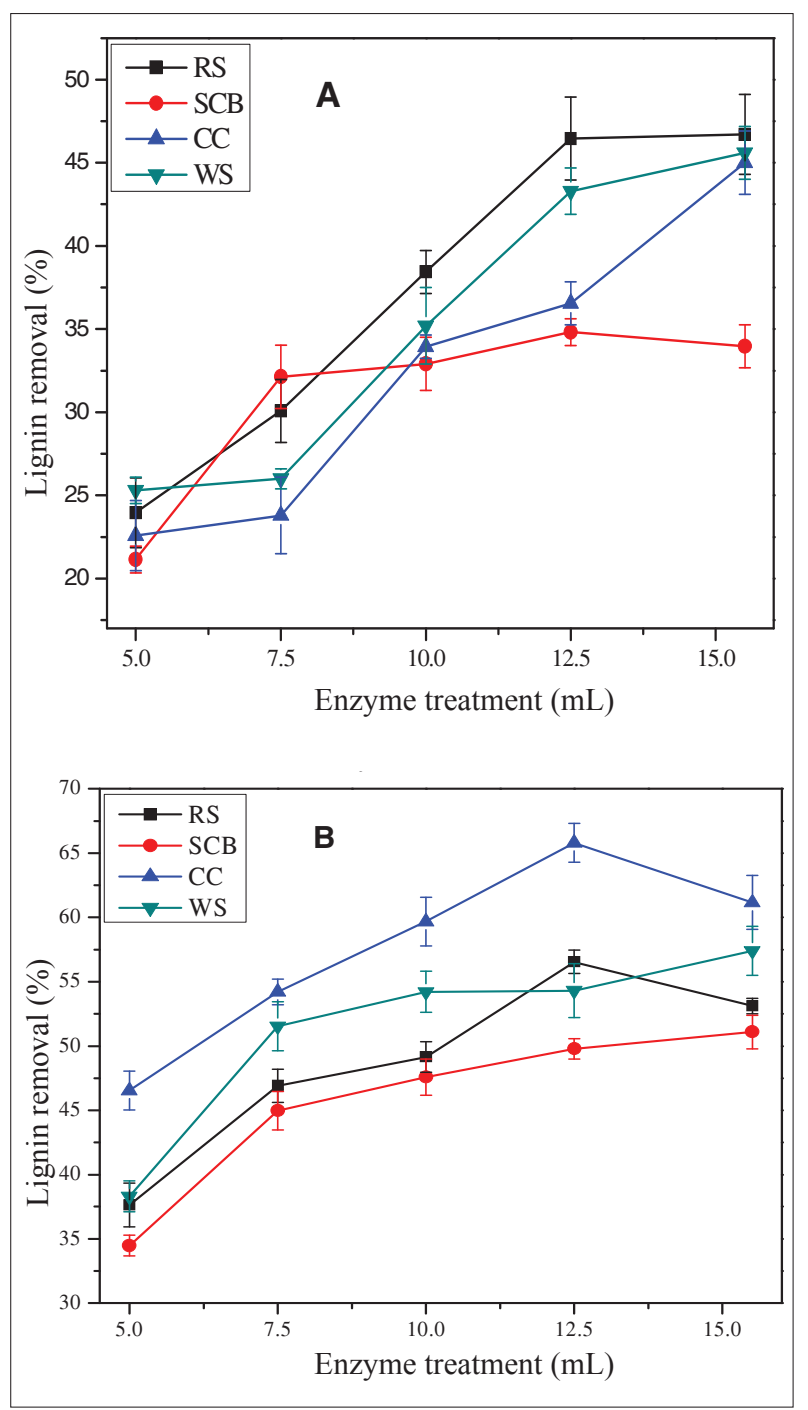

Figure 3: Delignification of different agricultural wastes by crude enzymatic extract from P. sapidus after (A) 24 hours and (B) 48 hours; RS - rice straw; SCB - sugarcane bagasse; CC - corncobs; WS - wheat straw

\section{CONCLUSION}

The present study has shown that the production of lignocellulolytic enzymes can easily be enhanced by optimisation of different process parameters through response surface methodology. The crude enzyme extract showed encouraging results for bio-delignification of various agricultural wastes.

\section{Acknowledgement}

The authors gratefully acknowledge the financial support from the Higher Education Commission, Islamabad, Pakistan. The Industrial Biotechnology Laboratory, Department of Biochemistry, University of Agriculture, Faisalabad, Pakistan is appreciated for logistical and moral support. The authors are also thankful to Dr Nasir Ahmad Khan for providing the fungal strain for this research study.

\section{REFERENCES}

1. Asad M.J., Asgher M., Sheikh M.A. \& Sultan J.I. (2006). Production of Neurospora sitophila cellulases in solid state cultures. Journal of the Chemical Society of Pakistan 28: $590-595$.

2. Asgher M., Ahmad Z. \& Iqbal H.M.N. (2013a). Alkali and enzymatic delignification of sugarcane bagasse to expose cellulose polymers for saccharification and bio-ethanol production. Industrial Crops and Products 44: 488 - 495. DOI: http://dx.doi.org/10.1016/j.indcrop.2012.10.005

3. Asgher M., Bashir F. \& Iqbal H.M.N. (2013b). A comprehensive ligninolytic pre-treatment approach from lignocellulose green biotechnology to produce bioethanol. Chemical Engineering Research and Design 92(8): $1571-1578$.

DOI: http://dx.doi.org/10.1016/j.cherd.2013.09.003

4. Bilal M. \& Asgher M. (2015). Dye decolorization and detoxification potential of Ca-alginate beads immobilized manganese peroxidase. BMC Biotechnology 15: 111. DOI: http://dx.doi.org/10.1186/s12896-015-0227-8

5. Fernández-Fueyo E., Castanera R., Ruiz-Dueñas F.J., López-Lucendo M.F., Ramírez L., Pisabarro A.G. \& Martínez A.T. (2014). Ligninolytic peroxidase gene expression by Pleurotus ostreatus: differential regulation in lignocellulose medium and effect of temperature and pH. Fungal Genetics Biology 72: 150 - 161.

DOI: http://dx.doi.org/10.1016/j.fgb.2014.02.003

6. Ferreira S., Duarte A.P., Ribeiro M.H., Queiroz J.A. \& Domingues F.C. (2009). Response surface optimization of enzymatic hydrolysis of Cistus ladanifer and Cytisus striatus for bioethanol production. Biochemical Engineering 45(3): 192 - 200.

DOI: http://dx.doi.org/10.1016/j.bej.2009.03.012

7. Gadgil N.J., Oaginkawala H.F., Chakarbati J. \& Khanna P. (1995). Enhanced cellulose production by a mutant of Trichoderma reesi. Enzyme and Microbial Technology 17: $942-956$.

DOI: http://dx.doi.org/10.1016/0141-0229(94)00131-A

8. Gielkens M.M.C., Dekkers E., Visser J. \& De Graaff L.H. (1999). Two cellobiohydrolaseencoding genes from 
Aspergillus niger require D-xylose and the xylanolytic transcriptional activator XlnR for their expression. Applied and Environmental Microbiology 65(10): 4340 - 4345.

9. Goyal M.\& Soni G. (2011). Production and characterization of cellulolytic enzymes by Pleurotus florida. Mycosphere 2(3): $249-254$.

10. Kalmis E., Yasa I., Kalyoncu F., Pazarbasi B. \& Kocyigit A. (2008). Ligninolytic enzyme activities in mycelium of some wild and commercial mushrooms. African Journal of Biotechnology 7(23): $4314-4320$.

11. Kotzamanidis C., Roukas T. \& Skaracis G. (2013). Optimization of lactic acid production from beet molasses by Lactobaccilus delbruckii NCIMB 8130. World Journal of Microbiology and Biotechnology 18: 441 - 448. DOI: http://dx.doi.org/10.1023/A:1015523126741

12. Mtui G.Y.S. (2012). Lignocellulolytic enzymes from tropical fungi: types, substrates and applications. Scientific Research Essays 7(15): 1544 - 1555.

13. Munir N., Asgher M., Tahir I.M., Riaz M., Bilal M. \& Shah S.M.A. (2015). Utilization of agrowastes for production of ligninolytic enzymes in liquid state fermentation by Phanerochaete chrysosporium-IBL-03. International Journal of Chemical and Biochemical Sciences 7: 9-14.

14. Silva M.L.C., Souza V.B., Santos V.S., Kamida H.M., Vasconcellos-Neto J.R.T., Goes-Neto A. \& Koblitz M.G.B. (2014). Production of manganese peroxidase by Trametes villosa on unexpensive substrate and its application in the removal of lignin from agricultural wastes. Advances in Bioscience and Biotechnology 5: 1067 - 1077. DOI: http://dx.doi.org/10.4236/abb.2014.514122

15. Singh M.P., Pandey A.K., Vishwakarma S.K., Srivastava A.K. \& Pandey V.K. (2012). Extracellular xylanase production by Pleurotus species on lignocellulosic wastes under in vivo condition using novel pretreatment. Cellular Molecular Biology 58(1): 170 - 173.

16. Taniguchi M., Suzuki H., Watanabe D., Sakai K., Hoshino K. \& Tanaka T. (2005). Evaluation of pretreatment with Pleurotus ostreatus for enzymatic hydrolysis of rice straw.
Journal of Bioscience and Bioengineering 100: 637 - 643 . DOI: http://dx.doi.org/10.1263/jbb.100.637

17. Tellez F., Fernandez J., Sanchez C. \& Godinez G. (2008). Laccase production in solid-state and submerged fermentation by Pleurotus ostreatus. Applied Microbiology and Biotechnology 81: $675-679$.

DOI: http://dx.doi.org/10.1007/s00253-008-1628-6

18. Tien M. \& Kirk T.K. (1988). Lignin peroxidase of Phanerochaete chrysporium. Methods in Enzymology 33: $569-575$.

19. Vassilev N., Requena A.R., Nieto L.M., Nikolaeva I. \& Vassilev M. (2009). Production of manganese peroxidase by Phanerochaete chrisosporium grown on medium containing agro-wastes/rock phosphate and biocontrol properties of the final product. Industrial Crops and Products 30: $28-32$.

DOI: http://dx.doi.org/10.1016/j.indcrop.2009.01.001

20. Wang F., Hu J., Guo C. \& Liu C. (2014). Enhanced laccase production by Trametes versicolor using corn steep liquor as both nitrogen source and inducer. Bioresource Technology 166: $602-605$.

DOI: http://dx.doi.org/10.1016/j.biortech.2014.05.068

21. Wariishi H., Valli K. \& Gold M.H. (1992). Manganese (II) oxidation by manganese peroxidase from the basidiomycete Phanerochaete chrysosporium. Kinetic mechanism and role of chelators. Journal of Biological Chemistry 267: $23688-23695$.

22. Wolfenden B.S. \& Willson R.L. (1982). Radical-cations as reference chromogens in kinetic studies of oneelectron transfer reactions: pulse radiolysis studies of 2 , 2 -azinobis-(3-ethylbenzthiazoline-6-sulphonate). Journal of Chemical Society of Perkin Transactions 7: 805 - 812. DOI: http://dx.doi.org/10.1039/P29820000805

23. Yasmeen Q., Asgher M., Sheikh M.A. \& Nawaz H. (2013). Optimization of ligninolytic enzymes production through response surface methodology. BioResources 8(1): $944-968$.

DOI: http://dx.doi.org/10.15376/biores.8.1.944-968 